\title{
Energy requirements of infants
}

\author{
Nancy F Butte* \\ USDA/ARS Children's Nutrition Research Center, Department of Pediatrics, Baylor College of Medicine, Houston, \\ Texas 77030, USA
}

\begin{abstract}
Objective: To estimate the energy requirements of infants from total energy expenditure and energy deposition during growth.

Design: Energy requirements during infancy were estimated from total energy expenditure measured by the doubly labelled water method and energy deposition based on measured protein and fat gains.

Setting: Database on the total energy expenditure and energy deposition of infants was compiled from available studies conducted in China, Chile, Gambia, Mexico, Netherlands, UK, and USA.

Subjects: Healthy, term infants.

Results: Total energy requirements $\left(\mathrm{kJ} \mathrm{day}^{-1}\right)$ increased with age and were higher in boys than girls due to differences in weight. Energy requirements decreased from $473 \mathrm{~kJ} \mathrm{~kg}^{-1}$ per day for boys and $447 \mathrm{~kJ} \mathrm{~kg}^{-1}$ per day for girls at 1 month of age to $337 \mathrm{~kJ} \mathrm{~kg}^{-1}$ per day for boys and $341 \mathrm{~kJ} \mathrm{~kg}^{-1}$ per day for girls at 6 months of age, and thereafter tended to plateau. Energy deposition as a percentage of total energy requirements decreased from $40 \%$ at 1 month to 3\% at 12 months of age. These estimates are 10-32\% lower than the $1985 \mathrm{FAO} / \mathrm{WHO} / \mathrm{UNU}$ recommendations which were based on observed energy intakes of infants.

Conclusions: Recommendations for the energy intake of infants should be revised based on new estimates of total energy expenditure and energy deposition.
\end{abstract}

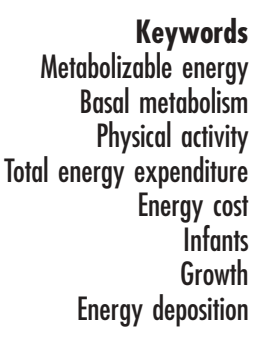

\section{Introduction and historical background}

In the $1985 \mathrm{FAO} / \mathrm{WHO} / \mathrm{UNU}$ publication, Energy and Protein Requirements ${ }^{1}$, the energy requirement of an individual is defined as the level of energy intake from food that will balance energy expenditure when the individual has a body size and composition, and level of physical activity, consistent with long-term good health; and that will allow for the maintenance of economically necessary and socially desirable physical activity. In children and pregnant or lactating women the energy requirement includes the energy needs associated with the deposition of tissues or the secretion of milk at rates consistent with good health.' To the extent possible, the recommendations incorporated the following concepts:

1. The energy needs of a group are represented by the average of the needs of individuals in that group. Most individuals have the ability to self-select their food intake in accordance with their energy requirement over the long term, since it is believed that regulatory mechanisms operate to maintain a balance between energy intake and energy requirement over long periods of time. One would expect a correlation between energy intake and energy requirement among individuals if sufficient food is available in the absence of interfering factors. 'For the requirement of classes, the estimate of average requirement is an appropriate descriptor for the distribution of requirement ${ }^{1}$.'

2. 'As a matter of principle, we believe that estimates of energy requirements should, as far as possible, be based on estimates of energy expenditure, whether actual or desirable. To determine requirements from observed intakes is largely a circular argument, since in both developing and developed countries actual intakes are not necessarily those that maintain a desirable body weight or optimal levels of physical activity, and hence health in its broadest sense. However, it has not been possible to follow this principle in the case of children, because we do not have enough information about their energy expenditure ${ }^{1}$.'

The first concept, that the energy needs of a group are represented by the average energy requirement of individuals in that group, is applicable to infants. There is evidence that energy intake is self-regulated ${ }^{2,3}$, and most probably matches energy requirements. In the 1996 IDECG publication, Energy Requirements of Infants ${ }^{4}$, the second 
concept was upheld and an argument was made for revision of the $1985 \mathrm{FAO} / \mathrm{WHO} / \mathrm{UNU}$ recommendations based on energy expenditure. The 1985 FAO/WHO/UNU recommendations for infants were based on a compilation of energy intakes of infants predating 1940 and up to 1980, representing 9046 data points ${ }^{5}$. Data analysis revealed a highly curvilinear relationship between energy intake per $\mathrm{kg}$ body weight and age in months. Because of the concern for a secular trend in infant feeding practices, i.e. different formulations of breast milk substitutes and later introduction of complementary foods, the energy intakes of wellnourished infants recorded after 1980, representing 3573 data points, were examined ${ }^{4}$. The best equations describing energy intake of infants were:

$$
\begin{aligned}
& \text { Energy intake }\left(\mathrm{kJ} \mathrm{day}^{-1}\right)=879-248 \text { Age }(\text { months })+ \\
& 156 \text { Feed type }+264 \text { Weight }(\mathrm{kg})+ \\
& 58 \text { age } \times \text { Feed type }+23 \text { age } \times \text { weight } \\
& r^{2}=0.80 ; n= 422
\end{aligned}
$$

Energy intake $\left(\mathrm{kcal} \mathrm{day}^{-1}\right)=210-59.2$ Age (months) +

$$
\begin{aligned}
& 37.2 \text { Feed type }+63.1 \text { Weight }(\mathrm{kg})+ \\
& 14.0 \text { age } \times \text { Feed type }+5.6 \text { age } \times \text { weight }
\end{aligned}
$$$$
r^{2}=0.80 ; n=101
$$

where Feed type is coded 0 for breast-fed and 1 for formula-fed.

Although evidence for a strong secular trend in energy intakes of infants was not found, energy intakes recorded after 1980 were found to be 2-15\% lower than the 1985 FAO/WHO/UNU recommendations ${ }^{1}$, partially due to the $5 \%$ increment added to the recommendations to account for presumed underestimation of intake, and partially due to changes in infant feeding practices. The $1985 \mathrm{FAO} /$ WHO/UNU recommendations did not reflect current observations of energy intake of infants.

Energy expenditure was not used to derive energy recommendations, not because information on BMR of infants was not available, but because reasonable allowances for physical activity were undefined. In the IDECG publication ${ }^{4}$, it was proposed that total energy expenditure (TEE) by the doubly labelled water (DLW) method could be used as the basis for new recommendations, with the strong caveat that data were limiting for the second 6 months of life. Of the 268 TEE data points of well-nourished infants, $90 \%$ of the values were on infants under 6 months of age.

Derivation of the energy requirements of infants also requires an estimate of the energy requirement for growth. In the IDECG report ${ }^{4}$, the energy cost of growth (ECG) was based upon median weights from the 1977 NCHS growth curves, and weight velocities and rates of fat and protein deposition estimated by Fomon et $a l^{6}{ }^{6}$ The total ECG declined throughout infancy from $25 \mathrm{~kJ} \mathrm{~g}^{-1}\left(5.9 \mathrm{kcal} \mathrm{g}^{-1}\right)$ at
$1-2$ months to $14 \mathrm{~kJ} \mathrm{~g}^{-1}\left(3.4 \mathrm{kcal} \mathrm{g}^{-1}\right)$ at $9-12$ months. In the $1985 \mathrm{FAO} / \mathrm{WHO} / \mathrm{UNU}$ report ${ }^{1}$, a value of $23 \mathrm{kJg}^{-1}$ $\left(5.6 \mathrm{kcal} \mathrm{g}^{-1}\right)$ gained was suggested for healthy term infants.

In the IDECG report ${ }^{4}$, total energy requirements were based on TEE plus energy deposition and found to be 9-39\% lower than the $\mathrm{FAO} / \mathrm{WHO} / \mathrm{UNU}$ recommendations ${ }^{1}$. Expansion of the DLW database on TEE of infants in terms of sample size, age range and geographic distribution across the entire age range of infancy was recommended at that time.

\section{Energy requirements of infants}

\section{Components of the energy requirement during infancy}

Energy requirements during infancy are equal to the sum of TEE and ECG. TEE may be partitioned into further components, i.e. basal metabolism, thermic effect of feeding (TEF), thermoregulation and physical activity. Direct calorimetry and respiratory gas exchange, also referred to as indirect calorimetry, have been used to measure the energy expenditure of infants.

\section{Energy balance}

The energy balance equation in infants is described as:

$$
\begin{aligned}
\text { Gross energy intake }= & \text { energy excreted }+ \text { energy expended } \\
& + \text { energy stored }
\end{aligned}
$$

Gross energy intake measured by combustion in a bomb calorimeter exceeds the energy available to the infant, since most foods are not completely absorbed and protein is oxidised incompletely. Fecal fat excretion, which depends on the type of milk and age of the infant, accounts for most of the energy losses. Fat is remarkably well absorbed from human milk; fat excretion ranges from 7.7 to $13.4 \%$ of intake in newborn infants, and $5 \%$ beyond the newborn period ${ }^{7}$. Fat excretion from cows' milk and infant formula are highly variable $(5-37 \%)$ and dependent on the fat source. The gross energy values for milk $\left(5.65 \mathrm{kcalg}^{-1}\right.$ protein, $3.95 \mathrm{kcalg}^{-1}$ carbohydrate and $9.25 \mathrm{kcal} \mathrm{day}^{-1}$ fat) may be used to estimate the gross energy intake ${ }^{8}$.

Metabolizable energy is defined as digestible energy minus the heat of combustion of urine. Atwater's energy values of $4 \mathrm{kcal} \mathrm{g}^{-1}$ protein or carbohydrate and $9 \mathrm{kcal} \mathrm{g}^{-1}$ have been used to convert the macronutrient composition of infant formulas to metabolizable energy. Application of the adult-derived Atwater's values to infant diets is satisfactory if the dietary fat is highly digestible and protein concentration modest. Because of higher excretory losses of nitrogenous substances and fat, metabolizable energy from higher protein formulas and cows' milk may be overestimated. Complete energy balance studies are limited in term infants; metabolizable energy averaged $92 \%$ in infants fed breast milk or cows' milk preparations?. 


\section{Basal metabolism}

Basal metabolic rate (BMR) is defined as the energy expended to maintain cellular and tissue processes fundamental to the organism. Specifically, it is the energy needed to maintain body temperature, support the minimal work of the heart and respiratory muscles, and supply the energy requirements of tissues at rest. The basal metabolism of infants is accounted for primarily by the brain, liver, heart, and kidney ${ }^{10}$. The contribution of the brain to basal metabolism is exceptionally high in the newborn period (70\%) and throughout the first years of life (60-65\%).

Conventionally, BMR is measured under standard conditions whereby the individual is at rest in a thermoneutral environment after a $12-18$ hour fast. The application of these criteria to infants would be impractical; thus, investigators have adopted various approaches to measure 'basal metabolism' in sleeping infants $^{11}$. Some investigators have used sedatives to induce sleep ${ }^{12}$; others have opted to feed the infant ${ }^{13}$. Sleep and some sedatives will lower BMR, whereas feeding will augment it.

Basal metabolism of term infants has been investigated extensively $^{12,13}$. Reported BMR ranges from 180 to $251 \mathrm{~kJ} \mathrm{~kg}^{-1}$ per day $\left(43-60 \mathrm{kcal} \mathrm{kg}^{-1}\right.$ per day). The high variability is attributable to biological differences in body composition, and technical differences in experimental conditions and methods. Schofield et al. compiled $\sim 300$ measurements from historical data to develop predictive models based on weight and length ${ }^{14}$. The prediction equations for BMR of healthy children under the age of 3 years are as follows:

$$
\begin{aligned}
& \text { Boys: } \operatorname{BMR}(\mathrm{MJ} \text { day })= \\
& \text { 0.0007 Weight }(\mathrm{kg})+6.349 \text { Length }(\mathrm{m})-2.584 \text {; } \\
& r=0.97, \text { SEE }=0.24 \\
& \text { Girls: } \operatorname{BMR}(\text { MJ day })= \\
& 0.068 \text { Weight }(\mathrm{kg})+4.281 \text { Length }(\mathrm{m})-1.730 \text {; } \\
& r=0.97, \text { SEE }=0.22 \\
& \text { Boys: } \operatorname{BMR}\left(\mathrm{kcal} \mathrm{day}^{-1}\right)= \\
& 0.1673 \text { Weight }(\mathrm{kg})+1517 \text { Length }(\mathrm{m})-618 \text {; } \\
& r=0.97, \mathrm{SEE}=57 \\
& \text { Girls: } \operatorname{BMR}\left(\text { kcal day }^{-1}\right)= \\
& \text { 16.25 Weight }(\mathrm{kg})+1023 \text { Length }(\mathrm{m})-413 \text {; } \\
& r=0.97, \mathrm{SEE}=52
\end{aligned}
$$

These equations have been evaluated in more recent investigations, and have been found to underestimate BMR at early ages. The influence of neonatal age and sedation on the measurements of BMR might explain the lower values predicted by the Schofield equation compared with more recent measurements. Butte et al. ${ }^{11,16}$ measured Sleeping BMRs (SMR) in a series of 76 infants during the first 2 years of life. BMR predicted from weight and length using the Schofield equation ${ }^{14}$ was equal to 0.88 SMR at 3-12 months, 0.93 SMR at 18 months and 1.00 SMR at 24 months. Prediction equations for SMR were developed as follows ${ }^{16}$ :

$$
\begin{aligned}
& \text { SMR }\left(\text { MJ day }^{-1}\right)=-1.20-0.009 \text { Age }(\text { months })- \\
& \text { 0.061 Sex }+0.132 \text { Feed type }+0.122 \text { Weight }(\mathrm{kg})+ \\
& 0.032 \text { Length }(\mathrm{cm})-0.010 \text { Feed type } \times \text { Age; } \\
& r=0.88, \mathrm{SEE}=0.21 \\
& \text { SMR }\left(\mathrm{kcal} \mathrm{day}^{-1}\right)=-287-2.15 \text { Age }(\text { months })- \\
& \text { 14.6 Sex }+31.5 \text { Feed type }+29.2 \text { Weight }(\mathrm{kg})+ \\
& \text { 7.6 Length }(\mathrm{cm})-2.4 \text { Feed type } \times \text { Age; } \\
& r=0.88, \text { SEE }=50
\end{aligned}
$$

where sex is coded 1 for boys and 2 for girls, and feed type is coded 1 for breast-fed and 2 for formula-fed.

Wells $^{17}$ also reported poor agreement between measured SMR and BMR predicted by the Schofield equation $^{14}$. The percentage error was $-13,-8,-5,-7$, and $-1 \%$ at $1.5,3,6,9$, and 12 months of age. Prediction equations for SMR were also developed on 40 infants in the first year of life ${ }^{17}$ :

$$
\begin{aligned}
& \text { Boys : } \log \operatorname{SMR}\left(\mathrm{MJ} \mathrm{day}^{-1}\right)= \\
& 0.378 \log \text { Weight }(\mathrm{kg})+1.55 \log \text { Length }(\mathrm{m})-6.72 \text {; } \\
& r=0.88, \text { SEE }=0.17 \\
& \text { Girls : } \log \text { SMR }\left(\mathrm{MJ} \mathrm{day}^{-1}\right)= \\
& 0.427 \log \text { Weight }(\mathrm{kg})+1.16 \log \text { Length }(\mathrm{m})-5.23 \text {; } \\
& r=0.85, \text { SEE }=0.16 \\
& \text { Boys : } \log \operatorname{SMR}\left(\mathrm{kcal} \mathrm{day}^{-1}\right)= \\
& 90 \text { log Weight }(\mathrm{kg})+370 \text { log Length }(\mathrm{m})-1606 \text {; } \\
& r=0.88, \mathrm{SEE}=41 \\
& \text { Girls : } \log \operatorname{SMR}\left(\mathrm{kcal} \mathrm{day}^{-1}\right)= \\
& 102 \log \text { Weight }(\mathrm{kg})+277 \log \text { Length }(\mathrm{m})-1250 \text {; } \\
& r=0.85, \text { SEE }=38
\end{aligned}
$$

\section{Thermic effect of feeding}

The energy expended above basal metabolism in response to feeding, or the thermic effect of feeding, is referred to as the TEF. The TEF amounts to approximately 
$10 \%$ of the daily energy expenditure ${ }^{18}$. The major part of the rise in energy expenditure after a meal is due to the metabolic costs of transporting and converting the absorbed nutrients into their respective storage forms. The TEF in preterm infants ${ }^{19}$ and in infants recovering from malnutrition ${ }^{20}$ has been shown to be proportional to the rate of weight gain. These observations support the view that the increased energy expenditure is due to the metabolic costs of tissue synthesis.

\section{Thermoregulation}

Thermoregulation constitutes an additional energy cost when infants are exposed to temperatures below and above their zone of thermoneutrality. The environmental temperature at which oxygen consumption and metabolic rate are at their lowest is described as the thermoneutral zone $\mathrm{e}^{21}$. In the first 24 hours after birth, this temperature is $34-36^{\circ} \mathrm{C}$ for the naked infant and falls to $30-32^{\circ}$ by $7-10$ days of age. The amount of energy required to maintain normal body temperature is greater at lower than at higher temperatures. At temperatures below the critical temperature, i.e. the lower end of the thermoneutral zone, energy expenditure increases proportionately to the drop in environmental temperature.

The neonate responds to cold exposure with an increase in metabolic rate, which is thought to be mediated by increased sympathetic tone. Neonatal heat production occurs mainly by non-shivering thermogenesis $^{22}$. Oxidation of brown adipose tissue located between the scapulae, in the posterior triangle of the neck, and around major vessels and organs of the mediastinum and abdomen, is thought to make the most important contribution to non-shivering thermogenesis in infants.

\section{Physical activity}

Physical activity represents a component of TEE that increases as the infant grows and develops. Up until recently, the energy cost of activity could be estimated from a very limited set of infant data. Using respiratory calorimetry, 24-hour energy expenditure was measured in two term breast-fed infants, 3 and 6 months of age $e^{23}$. Twenty-four-hour energy expenditure rates, 310 and $293 \mathrm{~kJ} \mathrm{~kg}^{-1}$ per day (74 and $70 \mathrm{kcal} \mathrm{kg}^{-1}$ per day), were only 20-30\% above basal. Talbot suggested adding 15, 25, and $40 \%$ to basal metabolic rates to cover the activity needs of very quiet, normally active, and extremely active infants, respectively ${ }^{23}$. Based on calorimetric studies of 70 healthy, full-term infants, Benedict and Talbot ${ }^{13}$ estimated that activity may represent as much as $40 \%$ of TEE. The peak of energy expenditure of activity occurred at 6 months; thereafter, voluntary muscular control became more coordinated, and the energy expenditure more efficient.
The DLW technique combined with calorimetry allows an estimate of activity energy expenditure (AEE). Energy expended on physical activity may be estimated from the difference between TEE and BMR, since most BMR measurements have been made in the fed state and because growth is thought to be a continuous process, the BMR includes the thermic effect of feeding and the energy cost of tissue synthesis. Wells et al. ${ }^{15}$ reported AEE was $22 \%$ of TEE in 3 month old infants. In a longitudinal study, AEE increased from $270 \mathrm{~kJ} \mathrm{day}^{-1}\left(64 \mathrm{kcalday}^{-1}\right)$ at 3 months to $1124 \mathrm{~kJ} \mathrm{day}^{-1}$ (269 $\mathrm{kcal} \mathrm{day}^{-1}$ ) at 24 months $^{16}$. Physical activity level (PAL) increased from 1.2 at 3 months to 1.4 at 24 months of age.

Lower levels of activity have been reported in undernourished infants and children ${ }^{24}$. Activity levels of infants studied in The Gambia were lower than those of a comparable group in the UK; differences, however, were attributed to socio-cultural factors rather than differences in nutritional status.

\section{Total energy expenditure}

TEE of infants encompasses basal metabolism, thermoregulation, physical activity, and the synthetic cost of growth. The DLW method, which has been validated in preterm infants and hospitalised term infants, may be used to measure TEE in infants. In the validation studies, mean errors between the DLW method and respiration calorimetry were $0.3 \pm 2.6 \%{ }^{25}$, $-0.9 \pm 6.2 \%^{26},-4.5 \pm 6.0 \%{ }^{27}$, and $-0.4 \pm 11.5 \%{ }^{28}$.

Published mean data on the TEE of infants living in developed and developing countries are summarised in Table 1. Standardised by weight, TEE ranged from 255 to $393 \mathrm{~kJ} \mathrm{~kg}^{-1}$ per day (61-94 $\mathrm{kcal} \mathrm{kg}^{-1}$ per day), increasing linearly with age. TEE of breast-fed infants was shown to be lower than formula-fed infants ${ }^{16,29-31}$. Energy expenditure was 12, 7, 6, 3, 0 and 1\% higher in formula-fed than breast-fed infants at 3, 6, 9, 12, 18 and 24 months, respectively, indicating that differences in TEE between feeding groups diminish beyond the first year of life $e^{16}$.

Several published TEE studies are available on presumably well-nourished infants living in developed countries (Table 1). Individual TEE data were available for further analysis from the study published by Butte et al. ${ }^{16}$ These TEE data were on 76 healthy infants ( $n=40$ breastfed and $n=36$ formula-fed infants) studied longitudinally throughout the first 2 years of life ${ }^{16}$. The linear relationship between TEE and weight is graphically displayed in Fig. 1, with 95\% prediction and confidence intervals. The coefficient of variation was fairly uniform across age: 21.0, 18.0, 15.4, 17.7, 17.7 and 16.0\% at 3, 6, 9, 12, 18 and 24 months, respectively. TEE differed by age, sex (boys $>$ girls) and feeding group (formula-fed $>$ breastfed). TEE was significantly affected by weight and height. Because of the high correlations between age, weight and height ( $r=0.91-0.96)$, they were all good predictors 


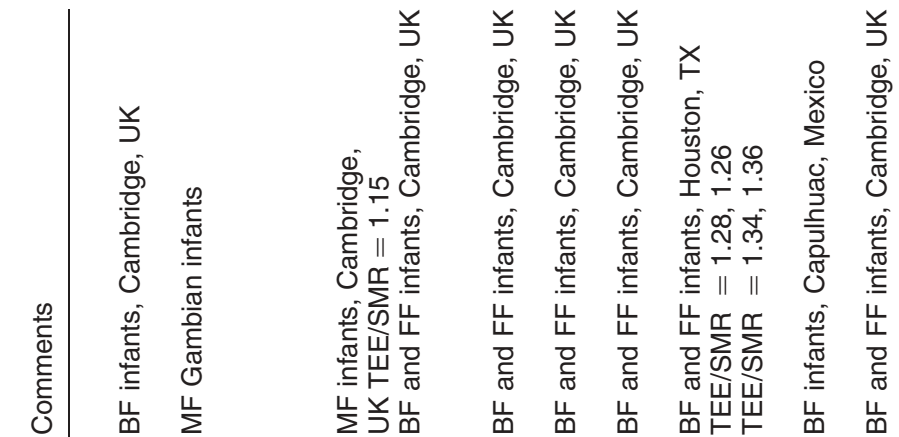

S.

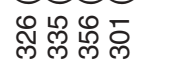

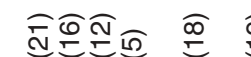

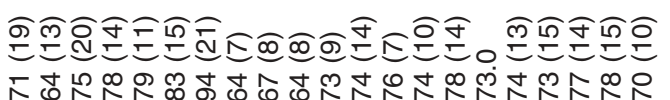

$\widehat{ด} N$

인에

$\overline{6}$

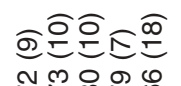

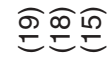

№m

我穴下

จิำ

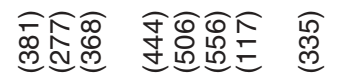

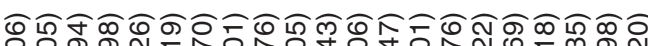

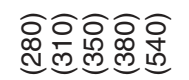

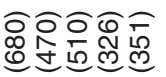

때요욤

离品莒

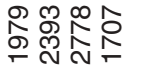

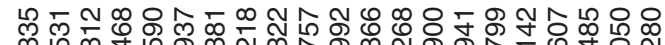

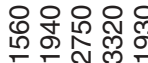

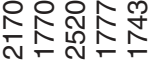

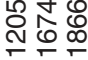

㟧

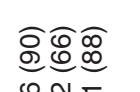

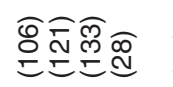

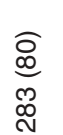

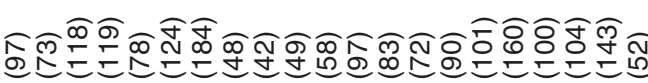

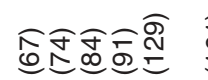

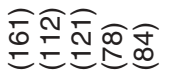
扊京品

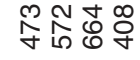

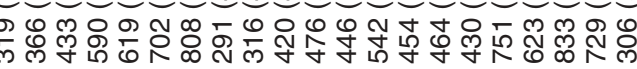

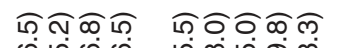
ம்ம் ம் ம்ம் $\infty 0+\infty+0$ 十 00

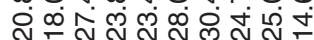

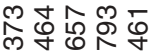

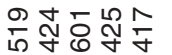

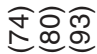

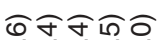
लं $\infty$ N $N$ L 0

อิกฺิ์

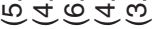

約度导

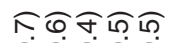

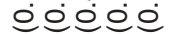

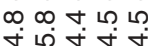

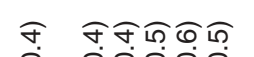

ㅇ

जबत

于०ิ0

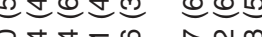

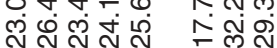

$\sum_{1} \frac{\widehat{D}}{\Perp}$

드ำ

อ

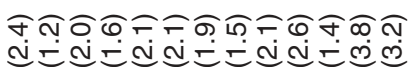

Nơ

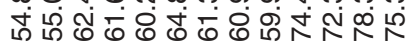

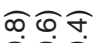

อंe

ำ

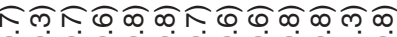

$\stackrel{5}{\circ: 0}$

écócócócó

守官守

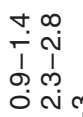

क

(م)

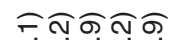

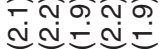

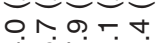

เิซ

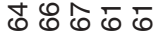

อㅇำ

$\stackrel{\forall}{\sim} \stackrel{\sim}{\sim}$

กิธ

$\underset{\infty}{\infty}=$

$8 \dot{0}$

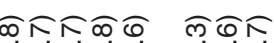

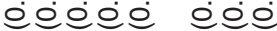

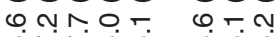

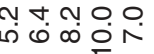

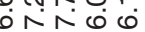

अं

$\begin{array}{lll}1 & 0 \\ 1 & 0 & 1 \\ 0 & 1 & 0\end{array}$

(n)

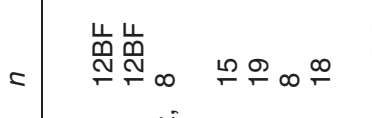

岗

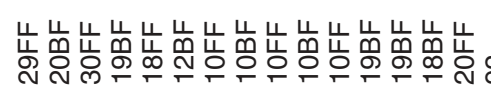

$1 \frac{10}{10}$

崖壵

$\infty \infty$

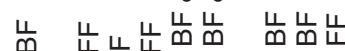

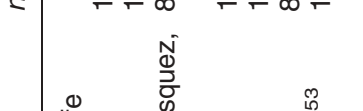

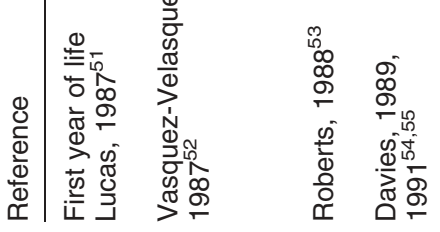

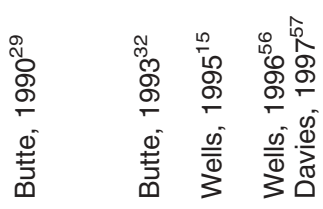

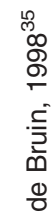

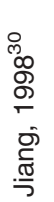

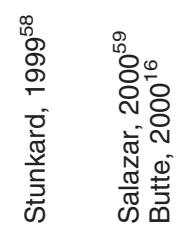


of TEE, with a slight advantage for weight. Since independent effects of age, sex and height were not demonstrated with weight entered, TEE for all infants was predicted simply from weight:

$$
\begin{gathered}
\operatorname{TEE}\left(\mathrm{kJ} \mathrm{day}^{-1}\right)=371 \text { Weight }(\mathrm{kg})-416, \quad \text { SEE }=456 \\
\operatorname{TEE}\left(\mathrm{kcal} \mathrm{day}^{-1}\right)=88.6 \text { Weight }(\mathrm{kg})-99.4, \quad \text { SEE }=109
\end{gathered}
$$

TEE for the breast-fed infants may be predicted from weight:

$$
\begin{gathered}
\operatorname{TEE}\left(\mathrm{kJ} \mathrm{day}^{-1}\right)=388 \text { Weight }(\mathrm{kg})-635, \quad \text { SEE }=453 \\
\operatorname{TEE}\left(\mathrm{kcal} \mathrm{day}^{-1}\right)=92.8 \text { Weight }(\mathrm{kg})-152, \quad \text { SEE }=108
\end{gathered}
$$

TEE for formula-fed infants may be predicted from weight:

$$
\begin{gathered}
\operatorname{TEE}\left(\mathrm{kJ} \mathrm{day}^{-1}\right)=346 \operatorname{Weight}(\mathrm{kg})-122, \quad \text { SEE }=463 \\
\operatorname{TEE}\left(\mathrm{kcal} \mathrm{day}^{-1}\right)=82.6 \operatorname{Weight}(\mathrm{kg})-29.0, \quad \text { SEE }=110
\end{gathered}
$$

In order to compare the regression equations derived from the individual TEE data with mean TEE values from other studies, linear regressions of mean TEE values on mean weights, weighed for sample sizes were performed, with and without Butte et al. data ${ }^{16}$.

$$
\begin{aligned}
& \text { TEE }\left(\mathrm{kJ} \mathrm{day}^{-1}\right)=369 \text { Weight }(\mathrm{kg})-399 \\
& \text { (including Butte et al.) } \\
& \operatorname{TEE}\left(\mathrm{kcal} \mathrm{day}^{-1}\right)=88.3 \text { Weight }(\mathrm{kg})-95.4 \\
& \text { (including Butte et al.) } \\
& \text { TEE }\left(\mathrm{kJ} \mathrm{day}^{-1}\right)=374 \text { Weight }(\mathrm{kg})-409 \\
& \text { (excluding Butte et al.) } \\
& \text { TEE }\left(\mathrm{kcal} \mathrm{day}^{-1}\right)=89.5 \text { Weight }(\mathrm{kg})-97.8 \\
& \text { (excluding Butte et al.) }
\end{aligned}
$$

A limited number of TEE studies is available on infants living in developing countries who may be undernourished and exposed to harsher environmental conditions. Chilean infants studied at 1 month of age had TEE similar to well-nourished breast-fed infants in developed countries. A study was conducted in The Gambia where the infants were undernourished $(65 \%<90$ th percentile weight for age) and stunted (36\% < 90th percentile weight for height). In another study of Mexican infants who had low weight-for-age and length-for-age Z-scores, TEE per $\mathrm{kg}$ body weight was significantly higher in the Mexican than American breast-fed infants ${ }^{32}$. Normalised for Fat free mass (FFM), the differences in TEE between cohorts diminished, but remained significant. Energy expenditure 


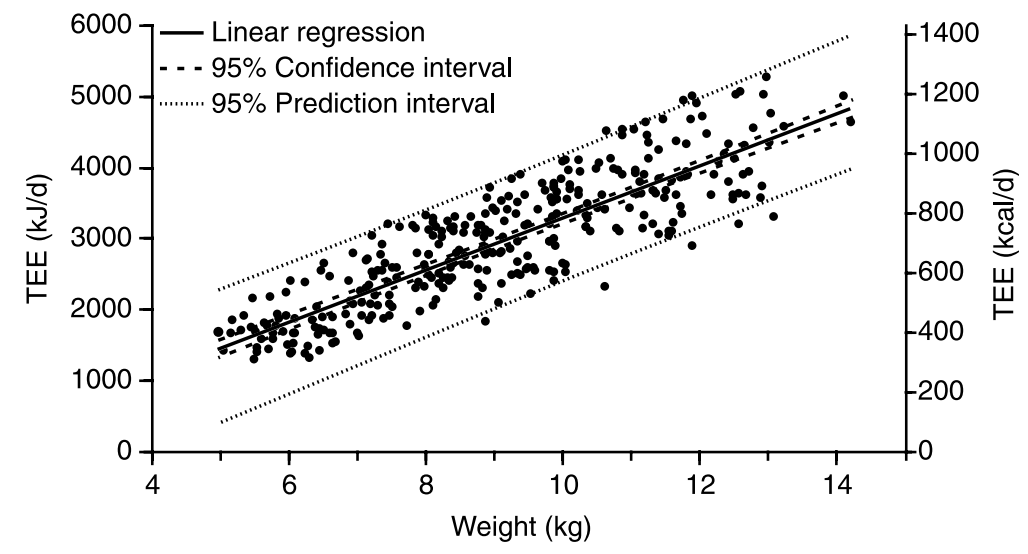

Fig. 1 Linear regression with 95\% prediction and confidence intervals of total energy expenditure (TEE) by doubly labelled water method on weight, measured longitudinally on 76 healthy infants ( $n=40$ breast-fed and $n=36$ formula-fed infants) throughout the first 2 years of life ${ }^{16}$

of malnourished Peruvian infants undergoing catch-up growth was elevated compared to well-nourished infants ${ }^{33}$. Their relatively high proportion of FFM accounted for the elevated TEE per unit body weight. A series of DLW studies was also conducted on Chinese breast-fed and formula-fed infants ${ }^{30}$.

Mean TEE values ( $\mathrm{kJ} \mathrm{day}^{-1}$, $\mathrm{kcal} \mathrm{day}^{-1}$ ) of infants living in developing versus developed countries are plotted as a function of mean weight in Fig. 2. The regression equations derived from mean TEE on mean weights, weighted for sample sizes, for infants living in developing countries were:

$$
\begin{gathered}
\operatorname{TEE}\left(\mathrm{kJ} \mathrm{day}^{-1}\right)=397 \text { Weight }(\mathrm{kg})-527 \\
\operatorname{TEE}\left(\mathrm{kcal} \mathrm{day}^{-1}\right)=95.0 \text { Weight }(\mathrm{kg})-126
\end{gathered}
$$

For a given weight, TEE tended to be higher in infants from developing than developed countries. Least squares regression, weighed by sample size, revealed a significant effect of weight and origin (developed or developing country) on TEE. Further studies are needed to confirm whether the increased TEE is due solely to differences in size and body composition or other mitigating factors.

\section{Growth}

Although the energy requirement for growth relative to maintenance is small, except for the first months of life, satisfactory growth is a sensitive indicator of whether energy needs are being met. The ECG may be divided into two components: the energy content of the tissues and the energy needed for synthetic processes. The ECG may be computed from the separate costs of protein and fat deposition, since the components of weight gain change dramatically through the first year of life. Much of our understanding of the ECG has been derived from preterm infants or children recovering from malnutrition (Table 2) 34. Typically, the ECG in these studies ranges from 10 to $25 \mathrm{~kJ} \mathrm{~g}^{-1}\left(2.4-6.0 \mathrm{kcalg}^{-1}\right)$, as the composition of the tissue synthesised varies. Based on the changes in body composition of Fomon's term infant reference ${ }^{6}$, the total ECG fell from $\sim 25$ to $14 \mathrm{~kJ} \mathrm{~g}^{-1}\left(6-3.4 \mathrm{kcal} \mathrm{g}^{-1}\right)$ in the first year of life (Table 3 ).

Serial body composition measurements by TOBEC $^{35}$ and by a multi-component model based on TBW, TBK

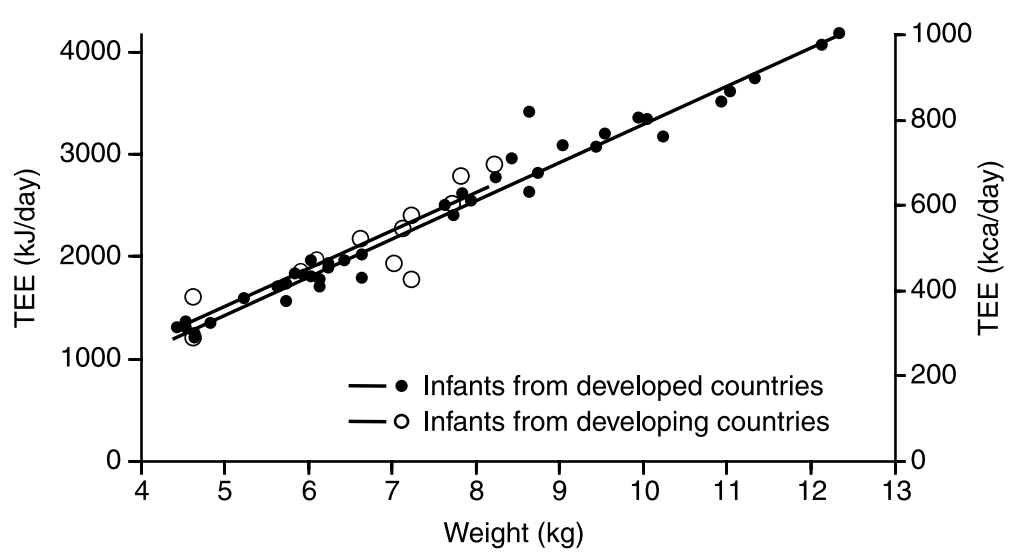

Fig. 2 Mean total energy expenditure (TEE) values of infants living in developing $(O)$ vs. developed $(\bullet)$ countries are plotted as a function of mean weight 
and $\mathrm{BMC}^{16}$ can be used to estimate energy deposition from protein and fat gains. Energy deposition averaged $259,556,447,224$, and $127 \mathrm{~kJ} \mathrm{day}^{-1}(62,133,107,54$, and $30 \mathrm{kcal} \mathrm{day}^{-1}$ ) at $0-1,1-2,2-4,4-8$, and 8-12 months of age, respectively, in one study ${ }^{35}$, and 490, 155, 90, 90, 75, and $65 \mathrm{~kJ} \mathrm{day}^{-1}\left(117,37,22,22,18\right.$ and $\left.16 \mathrm{kcal} \mathrm{day}^{-1}\right)$ at 3, $6,9,12,18$, and 24 months of age, respectively, in another $^{16}$. Energy cost of tissue deposition decreased from $\sim 26 \mathrm{~kJ} \mathrm{~g}^{-1}\left(\sim 6.3 \mathrm{kcalg}^{-1}\right)$ at $0-3$ months to $\sim 10 \mathrm{~kJ} \mathrm{~g}^{-1}$ $\left(\sim 2.3 \mathrm{kcalg}^{-1}\right)$ at $9-12$ months (Table 4$)$. These values were applied to the weight velocities observed in the WHO pooled data set of breast-fed infants to estimate the rates of energy deposition ${ }^{36}$.

\section{Catch-up growth}

Catch-up growth here refers to restoration of normal weight for height in a child who has been malnourished ${ }^{37,38}$. Astonishingly high rates of growth have been observed in wasted infants, up to 20 times normal rates. The average rate of growth of children who are only stunted is slower, about three times normal rates. Notwithstanding the need for energy and protein, all the essential nutrients required for tissue synthesis must be available for catch-up growth. The extent of the initial deficit, composition of gain, protein quality, and the efficiency of protein utilisation will affect the rates of catch-up growth.
The energy expenditure of infants recovering from malnutrition has been studied using indirect calorimetry and more recently using the doubly labelled water method. The TEE of Peruvian infants, 3-18 months of age, was 347 and $318 \mathrm{~kJ} \mathrm{~kg}^{-1}$ per day ( 83 and $76 \mathrm{kcal} \mathrm{kg}^{-1}$ per day), respectively, during the early and late phases of recovery from malnutrition ${ }^{33}$. Malnourished infants have been shown to have depressed metabolic rates ${ }^{39}$ although the data are equivocal ${ }^{40}$. When infants are refed, their metabolic rates rise rapidly long before FFM is repleted, suggesting immediate restoration of normal cellular respiration.

The energy requirement for maintenance takes precedence over protein synthesis. Protein synthesis is a high energy-requiring process, and the supply of energy influences the rate of whole body protein metabolism. Over the range of energy intake, $251-1130 \mathrm{~kJ} \mathrm{~kg}^{-1}$ per day (60-270 kcal kg ${ }^{-1}$ per day), energy intake and the rate of protein turnover are positively correlated ${ }^{41}$. When energy intake is below maintenance needs, growth will cease. As the rate of weight gain increases, the protein requirement increases proportionately more than the requirement for energy $^{38}$ (Table 5).

Rapid weight gain during catch-up growth can restore normal body composition, if adequate protein is provided. Energy cost of tissue deposition (24

Table 2 Energy balance studies used to compute the energy cost of growth

\begin{tabular}{|c|c|c|c|c|c|c|c|c|c|c|}
\hline \multirow[b]{2}{*}{ Reference } & \multirow[b]{2}{*}{$n$} & \multirow[b]{2}{*}{$\begin{array}{c}\text { Age } \\
\text { (months) }\end{array}$} & \multirow[b]{2}{*}{$\begin{array}{l}\text { Weight } \\
(\mathrm{kg})\end{array}$} & \multicolumn{3}{|c|}{ Weight gain } & \multicolumn{2}{|c|}{$\mathrm{E}_{\text {components }}$} & \multicolumn{2}{|c|}{$\mathrm{E}_{\text {synthesis }}$} \\
\hline & & & & 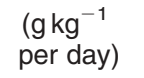 & $\begin{array}{c}E_{c g} \\
(k J g)\end{array}$ & $\left(\mathrm{kcal} \mathrm{g}^{-1}\right)$ & $\left(\mathrm{kJ} \mathrm{g}^{-1}\right)$ & $\left(\mathrm{kcal} \mathrm{g}^{-1}\right)$ & $\left(\mathrm{kJ} \mathrm{g}^{-1}\right)$ & $\left(\mathrm{kcalg}^{-1}\right)$ \\
\hline \multicolumn{11}{|c|}{ Infants recovering from malnutrition } \\
\hline \multirow[t]{2}{*}{ Ashworth, $1969^{20}$} & 8 & $16.5(8.1)^{\mathrm{a}}$ & $5.1(1.1)$ & $10.0(1.3)$ & $40.2(7.1)^{b}$ & $9.6(1.7)$ & - & & - & \\
\hline & & - & - & $7.8(0.9)$ & $46.4(4.6)$ & $11.1(1.1)$ & - & & - & \\
\hline Kerr et al., $1973^{62}$ & 50 & 12.9 & - & - & $25.1^{\mathrm{c}}$ & 6.0 & $19.7^{d}$ & 4.7 & - & \\
\hline Spady et al., $1976^{63}$ & 11 & $12.2(3.6)$ & $5.2(1.2)$ & $8.4(4.6)$ & $18.4^{\mathrm{c}}$ & 4.4 & $13.8(6.3)^{\mathrm{e}}$ & $3.3(1.5)$ & $4.6^{f}$ & 1.1 \\
\hline Jackson et al., $1977^{64}$ & 5 & $14.8(6.6)$ & $6.8(2.3)$ & - & - & & $25.9(10.9)^{\mathrm{e}}$ & $6.2(2.6)$ & - & \\
\hline \multirow[t]{2}{*}{ Fjeld et al., $1989^{33}$} & 11 & $15.2(7.0)$ & $6.1(1.3)$ & $5.7(0.7)$ & - & & $21.3(12.6)$ & $5.1(3.0)$ & & \\
\hline & 11 & $13.5(5.8)$ & $5.7(1.6)$ & $11.8(1.9)$ & - & & $24.3(8.4)$ & $5.8(2.0)$ & & \\
\hline \multirow[t]{2}{*}{ Fjeld et al., $1989^{45}$} & 22 & $16.0(6.5)$ & $7.0(1.3)$ & $7.3(3.8)$ & - & & $23.0(10.0)$ & $5.5(2.4)$ & $4.2(2.5)$ & $1.0(0.6)$ \\
\hline & 19 & $16.3(5.3)$ & $8.2(1.2)$ & $7.6(3.6)$ & - & & $23.4(10.5)$ & $5.6(2.5)$ & $4.2(2.5)$ & $1.0(0.6)$ \\
\hline \multirow[t]{3}{*}{ Graham et al., $1996^{65}$} & 14 & $9.5(2.2)$ & $5.4(0.7)$ & - & $31.8(7.1)$ & $7.6(1.7)$ & - & & - & \\
\hline & 15 & $11.2(3.0)$ & $6.0(0.7)$ & - & - & & - & & - & \\
\hline & 15 & $8.8(2.3)$ & $5.1(0.7)$ & - & - & & - & & - & \\
\hline \multicolumn{11}{|l|}{ Preterm infants } \\
\hline Brooke et al., $1979^{66}$ & 15 & $0-2$ & 1.9 & $13.7(4.9)$ & $23.8^{\mathrm{c}}$ & 5.7 & $16.7(2.5)^{d}$ & $4.0(0.6)$ & $7.1^{f}$ & 1.7 \\
\hline Chessex et al., $1981^{67}$ & 13 & $0-1$ & $1.2(0.2)$ & $13.9(5.0)$ & - & & - & & $2.8^{\mathrm{g}}$ & 0.7 \\
\hline Gudinchet et al., $1982^{68}$ & 15 & $0-2$ & $1.4(0.2)$ & $11.2(8.8)$ & - & & - & & $2.2^{\mathrm{g}}$ & 0.5 \\
\hline Reichman et al., $1982^{19}$ & 13 & $0-1$ & $1.3(0.2)$ & $16.8(3.6)$ & $20.5^{h}$ & 4.9 & $18.0^{\mathrm{e}}$ & 4.3 & $2.8^{\mathrm{g}}$ & 0.7 \\
\hline Whyte et al., $1982^{69}$ & 15 & $0-2$ & 1.9 & $13.7(4.9)$ & $18.4^{\mathrm{c}}$ & 4.4 & $15.5^{d}$ & 3.7 & - & \\
\hline Sauer et al., $1984^{70}$ & 14 & $0-2$ & $1.6(0.2)$ & $18.7(1.9)$ & - & & $11.7^{\mathrm{e}}(1.7)$ & $2.8(0.4)$ & $1.1(0.4)^{i}$ & $0.3(0.1)$ \\
\hline Freymond et al., $1986^{71}$ & 9 & $0-1$ & - & $16.6(4)$ & - & $4.0(1.0)$ & $10.9^{e}(2.9)$ & $2.6(0.7)$ & - & \\
\hline
\end{tabular}

${ }^{\mathrm{a}}$ Mean (SD).

${ }^{\mathrm{b}}$ Total energy cost of growth $\left(\mathrm{E}_{\mathrm{cg}}\right)=[$ Metabolizable energy intake (MEI) - basal metabolic rate (BMR)]/weight gain (WTG).

${ }^{c} E_{c g}=$ slope of regression of MEl on WTG.

${ }^{\mathrm{d} E n e r g y ~ d e p o s i t i o n ~ i n ~ t i s s u e s ~}\left(\mathrm{E}_{\text {components }}\right)=$ slope of regression of energy storage on WTG.

${ }^{e} \mathrm{E}_{\text {components }}=[\mathrm{MEI}-$ total daily energy expenditure (TDEE) $]$ WTG.

${ }^{\mathrm{f}}$ Energy cost of synthesis $\left(E_{\text {synthesis }}\right)=E_{c g}-E_{\text {components. }}$.

${ }^{g} E_{\text {synthesis }}=$ slope of regression of TDEE on WTG.

${ }^{h} E_{c g}=E_{\text {components }}+E_{\text {synthesis. }}$.

${ }^{\mathrm{i}} \mathrm{E}_{\text {synthesis }}=$ (metabolic rate - heat loss)/WTG. 


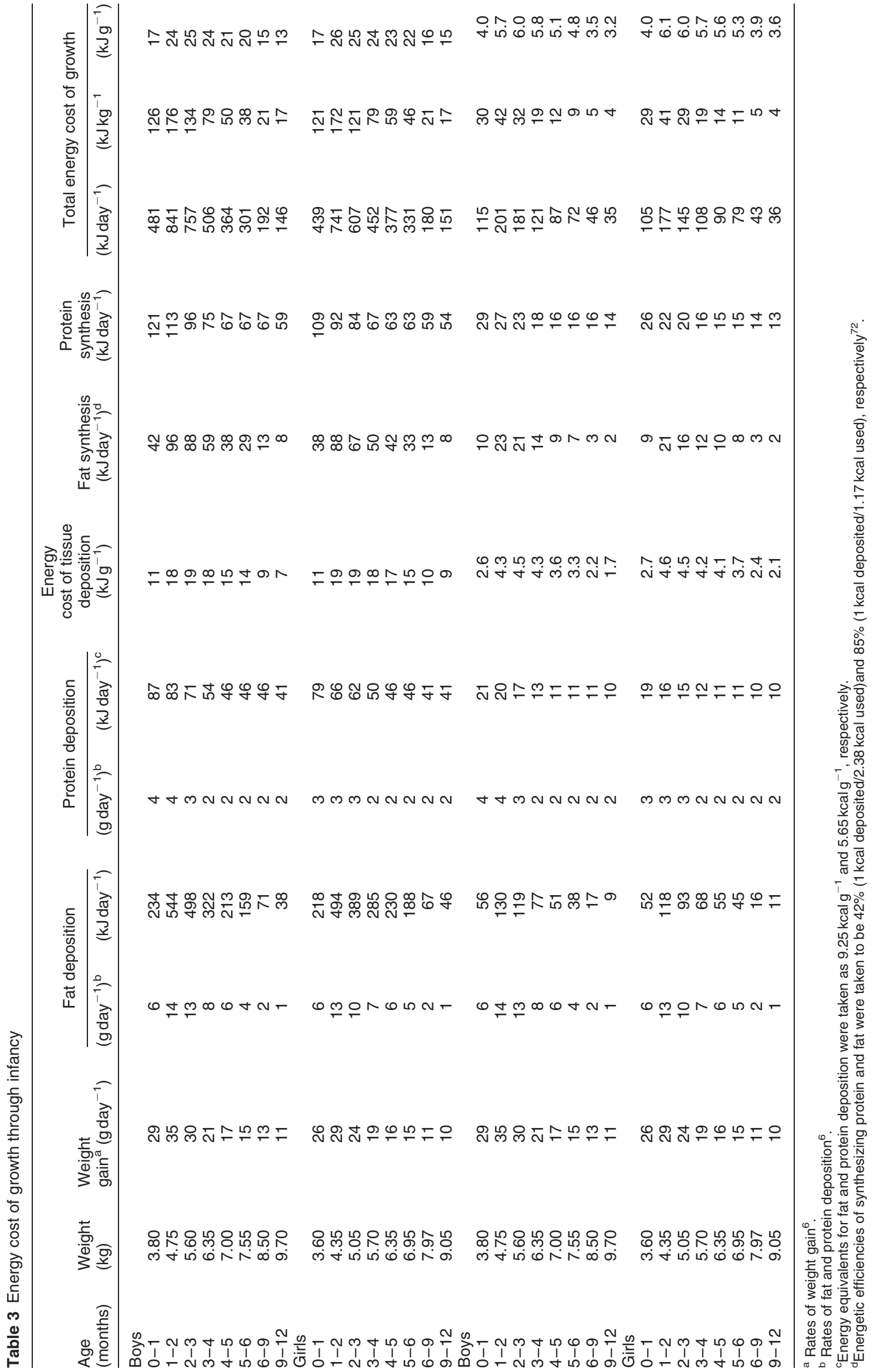


Table 4 Weight gain and energy deposition of infant girls and boys

\begin{tabular}{|c|c|c|c|c|c|c|c|}
\hline $\begin{array}{l}\text { Age interval } \\
\text { (months) }\end{array}$ & Protein gain $\left(\mathrm{g} \mathrm{day}^{-1}\right)^{\mathrm{a}}$ & FM gain $\left(\text { g day }^{-1}\right)^{a}$ & $\begin{array}{c}\text { Energy } \\
\text { cost of tissue } \\
\text { deposition } \\
\left(\mathrm{kJ} \mathrm{g}^{-1}\right)^{\mathrm{a}}\end{array}$ & $\begin{array}{c}\text { Energy } \\
\text { cost of tissue } \\
\text { deposition } \\
\left(\mathrm{kcal} \mathrm{g}^{-1}\right)^{\mathrm{a}}\end{array}$ & Weight gain $\left(\text { g day }^{-1}\right)^{b}$ & $\begin{array}{c}\text { Energy } \\
\text { deposition } \\
\left(\mathrm{kJ} \mathrm{day}^{-1}\right)^{\mathrm{b}}\end{array}$ & $\begin{array}{c}\text { Energy } \\
\text { deposition } \\
\left(\text { kcal day }^{-1}\right)^{\mathrm{b}}\end{array}$ \\
\hline \multicolumn{8}{|l|}{ Boys } \\
\hline $0-3$ & 2.6 & 19.6 & 25 & 6.0 & 30 & 753 & 180 \\
\hline $3-6$ & 2.3 & 3.9 & 12 & 2.8 & 17 & 197 & 47 \\
\hline $6-9$ & 2.3 & 0.5 & 6 & 1.5 & 11 & 67 & 16 \\
\hline $9-12$ & 1.6 & 1.7 & 11 & 2.7 & 8 & 92 & 22 \\
\hline \multicolumn{8}{|l|}{ Girls } \\
\hline $0-3$ & 2.2 & 19.7 & 26 & 6.3 & 28 & 732 & 175 \\
\hline $3-6$ & 1.9 & 5.8 & 15 & 3.7 & 16 & 251 & 60 \\
\hline $6-9$ & 2 & 0.8 & 8 & 1.8 & 10 & 75 & 18 \\
\hline $9-12$ & 1.8 & 1.1 & 10 & 2.3 & 6 & 58 & 14 \\
\hline
\end{tabular}

${ }^{\mathrm{a} E n e r g y ~ c o s t ~ o f ~ t i s s u e ~ d e p o s i t i o n ~}{ }^{73}$.

beight gain ${ }^{36}$.

and $21 \mathrm{~kJ} \mathrm{~g}^{-1}$ ) (5.8 and $\left.5.1 \mathrm{kcal} \mathrm{g}^{-1}\right)$ during rapid weight gain $\left(79 \mathrm{~g} \mathrm{day}^{-1}\right)$ did not differ statistically from that during moderate weight gain $\left(41 \mathrm{~g} \mathrm{day}^{-1}\right)^{42}$. In the early phase of recovery, the composition of weight gained was $20 \%$ protein, $40 \%$ fat and $40 \%$ water in the moderate gain group, and $14 \%$ protein, $43 \%$ fat and $43 \%$ water in the rapid gain group. In the late phase of recovery, the composition of gain did not differ statistically from the early phase. The observation that the rate of weight gain did not influence the composition of gain differs from previous reports ${ }^{43,44}$, in which hypercaloric feedings and accelerated weight gain led to increased fat deposition. However, it is possible that protein at 5-6.4\% of energy was limiting in the diet. Fjeld et $a l^{42}$ fed $544 \mathrm{~kJ} \mathrm{~kg}^{-1}$ per day (130 kcal kg-1 per day) and $3-4$ and $2-3 \mathrm{~g} \mathrm{~kg}^{-1}$ per day protein in the moderate gain group, and $711 \mathrm{~kJ} \mathrm{~kg}^{-1}$ per day $\left(170 \mathrm{kcal} \mathrm{kg}^{-1}\right.$ per day) and $4-5 \mathrm{~g} \mathrm{~kg}^{-1}$ per day protein in the rapid gain group, which was equivalent to $8-11 \%$ energy as protein.

A model to predict metabolizable energy (ME) requirements of children recovering from malnutrition was developed in 22 children ( $16 \pm 6$ months of age) based on TEE and body composition measurements ${ }^{45}$.
$\mathrm{ME}\left(\mathrm{kJ} \mathrm{kg}^{-1}\right.$ per day $)=410 \times \mathrm{FFM} / \mathrm{WT}+\mathrm{A}(46.4 \mathrm{~B}+9.2 \mathrm{C})$

$$
\mathrm{ME}\left(\mathrm{kcalkg}^{-1} \text { perday }\right)=98 \times \mathrm{FFM} / \mathrm{WT}+\mathrm{A}(11.1 \mathrm{~B}+2.2 \mathrm{C})
$$

where $\mathrm{A}$ is the rate of weight gain ( $\mathrm{g} \mathrm{kg}^{-1}$ per day); $\mathrm{B}$ is the fractional percentage of fat gain and $C$ is the fractional percentage of FFM gain.

WHO recommends two formulas for severely malnourished children, after clinical stabilisation ${ }^{46}$. The F-75 formulation is used during the initial phase of treatment, and the F-100 is used during the rehabilitation phase. The constituents of both include dried skimmed milk, sugar, cereal flour, vegetable oil, mineral mix, vitamin mix and water. During the initial phase, the child should be given at least $335 \mathrm{~kJ} \mathrm{~kg}^{-1}$ per day ( $80 \mathrm{kcal} \mathrm{kg}^{-1}$ per day), but not more than $418 \mathrm{~kJ} \mathrm{~kg}^{-1}$ per day ( $100 \mathrm{kcal} \mathrm{kg}^{-1}$ per day) of F75 formula. The F-75 formula has $315 \mathrm{~kJ}(75 \mathrm{kcal}) / 100 \mathrm{~mL}$, $0.9 \mathrm{~g}$ protein $/ 100 \mathrm{~mL}, 5 \%$ of energy from protein, and $32 \%$ from fat. When the child's appetite improves and clinical condition permits, he/she is ready for advancement to the F-100 formulation. The F-100 formula has $420 \mathrm{~kJ}$ (100 kcal)/ $100 \mathrm{~mL}, 2.9 \mathrm{~g}$ protein $/ 100 \mathrm{~mL}, 12 \%$ of energy from protein, and $53 \%$ from fat. The frequency and modality of feeding are critical, and outlined in the WHO publication ${ }^{46}$.

Table 5 Macronutrient requirements at different rates of weight gain

\begin{tabular}{lccccc}
\hline $\begin{array}{l}\text { Rate of weight } \\
\text { gain }\left(\mathrm{g} \mathrm{kg}^{-1} \text { per day) }\right.\end{array}$ & $\begin{array}{c}\mathrm{kJ} \mathrm{kg}^{-1} \\
\text { per day }\end{array}$ & $\begin{array}{c}\text { Energy } \\
\left(\mathrm{kcal} \mathrm{kg}^{-1} \text { per day }\right)^{\mathrm{a}}\end{array}$ & $\begin{array}{c}\text { Protein } \\
\left(\mathrm{g} \mathrm{kg}^{-1} \text { per day }\right)^{\mathrm{b}}\end{array}$ & $\begin{array}{c}\text { Protein } \\
(\mathrm{g} \text { protein/100 kcal) }\end{array}$ & $\begin{array}{c}\text { Protein:energy } \\
\text { ratio }(\%)\end{array}$ \\
\hline None & 356 & 85 & 0.62 & 0.73 & 2.9 \\
1 & 376 & 90 & 0.83 & 0.92 & 3.7 \\
2 & 393 & 94 & 1.04 & 1.55 & 4.4 \\
5 & 452 & 108 & 1.67 & 2.09 & 8.2 \\
10 & 544 & 130 & 4.72 & 2.77 & 11.1 \\
20 & 728 & 174 & 4.82 & & \\
\hline
\end{tabular}

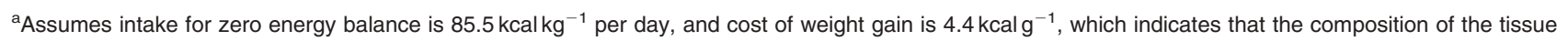
deposited is $73.5 \%$ lean and $26.5 \%$ fat.

${ }^{\mathrm{b}}$ Assumes intake for zero $\mathrm{N}$ balance is $100 \mathrm{mg} \mathrm{N} / \mathrm{kg}$ per day, protein content of weight gain is $14.7 \%$, and efficiency of dietary protein utilisation for tissue deposition is $70 \%$.

Modified from Ashworth and Millward, $1986^{38}$. 


\section{Influence of infections on energy requirements}

Infectious diseases heighten the demand for energy because of increased protein turnover, production of acute phase proteins and cytokines, tissue repair, proliferation of phagocytes and lymphocytes, and poor lipid utilisation with increased gluconeogenesis ${ }^{47}$. Intestinal parasites apparently have little or no effect on protein and energy requirements unless the infestation is extensive or causes diarrhoea. Anorexic effects, along with pyrexia, catabolic losses, and malabsorption, result in weight loss during infectious episodes.

The effect of infection on energy expenditure will depend on the type, severity and duration of the infection, as well as the nutritional status of the host ${ }^{47}$. The metabolic rate increases in response to fever by approximately 13\% for each $1^{\circ} \mathrm{C}$ rise in body; however, the response may be blunted in malnourished infants and may be compensated by behavioural adaptations. Undernourished Kenyan toddlers with measles showed no change in $\mathrm{RMR}^{48}$. Eccles et al. ${ }^{49}$ showed in Gambian infants that malaria suppressed SMR, accounting for the effect of fever. The lethargy, increased sleep, and bed rest associated with illness most likely outweigh any physiological increases in energy expenditure ${ }^{50}$.

Increased energy needs for catch-up growth following an infectious episode may not be met by the traditional $\operatorname{diet}^{37}$. High energy-density formulations may be needed during the short anabolic periods following episodes of weight loss to restore growth.

\section{Total energy requirement of infants}

Energy requirements of infants were derived from TEE measured by the DLW method and energy deposition based on rates of protein and fat gains ${ }^{16}$. Energy requirements are presented for all infants (Table 6), breast-fed infants (Table 7) and for formula-fed infants (Table 8). Total energy requirements naturally increase as the infants grow, and are higher in boys than girls due to differences in weight (Fig. 3). In contrast to the $1985 \mathrm{FAO} / \mathrm{WHO} / \mathrm{UNU}$ recommendations ${ }^{1}$, energy requirements adjusted for body weight do not display a curvilinear pattern (Fig. 4). Instead, energy requirements decrease from $473 \mathrm{~kJ} \mathrm{~kg}^{-1}$ per day for boys and $447 \mathrm{~kJ} \mathrm{~kg}^{-1}$ per day for girls at 1 month of age to $337 \mathrm{~kJ} \mathrm{~kg}^{-1}$ per day for boys and $341 \mathrm{~kJ} \mathrm{~kg}^{-1}$ per day for girls at 6 months, and thereafter tend to plateau. Energy deposition as a percentage of total energy requirement decreases from $40 \%$ at 1 month to 3\% at 12 months of age.

\section{Recommendations}

As outlined in the $1985 \mathrm{FAO} / \mathrm{WHO} / \mathrm{UNU}$ publication ${ }^{1}$, energy requirements during infancy may be represented by

Table 6 Energy requirements for all infants $0-12$ months of age

\begin{tabular}{|c|c|c|c|c|c|c|c|c|c|c|}
\hline $\begin{array}{l}\text { Age } \\
\text { (months) }\end{array}$ & $\begin{array}{l}\text { Weight } \\
(\mathrm{kg})^{\mathrm{a}}\end{array}$ & $\begin{array}{l}\text { Weight } \\
\text { velocity } \\
\left(\text { g day }^{-1}\right)^{b}\end{array}$ & $\begin{array}{c}\text { Total energy } \\
\text { expenditure } \\
\left(\mathrm{kJ} \mathrm{day}^{-1}\right)\end{array}$ & $\begin{array}{l}\text { Total energy } \\
\text { expenditure } \\
\left(\text { kcal day }^{-1}\right)\end{array}$ & $\begin{array}{c}\text { Energy } \\
\text { deposition } \\
\left(\mathrm{kJ} \mathrm{day}^{-1}\right)\end{array}$ & $\begin{array}{c}\text { Energy } \\
\text { deposition } \\
\left(\text { kcal day }^{-1}\right)\end{array}$ & $\begin{array}{c}\text { Energy } \\
\text { requirement } \\
\left(\mathrm{kJ} \mathrm{day}^{-1}\right)\end{array}$ & $\begin{array}{c}\text { Energy } \\
\text { requirement } \\
\left(\text { kcal day }^{-1}\right)\end{array}$ & $\begin{array}{l}\text { Energy } \\
\text { requirement } \\
\text { (kJ kg } \\
\text { per day) }\end{array}$ & $\begin{array}{l}\text { Energy } \\
\text { requirement } \\
\text { (kcal kg }^{-1} \\
\text { per day) }\end{array}$ \\
\hline \multicolumn{11}{|l|}{ Boys } \\
\hline 1 & 4.58 & 35.2 & 1282 & 306 & 884 & 211 & 2166 & 518 & 473 & 113 \\
\hline 2 & 5.5 & 30.4 & 1623 & 388 & 764 & 183 & 2387 & 570 & 434 & 104 \\
\hline 3 & 6.28 & 23.2 & 1912 & 457 & 582 & 139 & 2494 & 596 & 397 & 95 \\
\hline 4 & 6.94 & 19.1 & 2157 & 515 & 224 & 53 & 2380 & 569 & 343 & 82 \\
\hline 5 & 7.48 & 16.1 & 2357 & 563 & 189 & 45 & 2546 & 608 & 340 & 81 \\
\hline 6 & 7.93 & 12.8 & 2524 & 603 & 150 & 36 & 2674 & 639 & 337 & 81 \\
\hline 7 & 8.3 & 11.0 & 2661 & 636 & 69 & 17 & 2730 & 653 & 329 & 79 \\
\hline 8 & 8.62 & 10.4 & 2780 & 664 & 65 & 16 & 2845 & 680 & 330 & 79 \\
\hline 9 & 8.89 & 9.0 & 2880 & 688 & 57 & 14 & 2936 & 702 & 330 & 79 \\
\hline 10 & 9.13 & 7.9 & 2969 & 710 & 89 & 21 & 3058 & 731 & 335 & 80 \\
\hline 11 & 9.37 & 7.7 & 3058 & 731 & 87 & 21 & 3145 & 752 & 336 & 80 \\
\hline 12 & 9.62 & 8.2 & 3150 & 753 & 93 & 22 & 3243 & 775 & 337 & 81 \\
\hline \multicolumn{11}{|l|}{ Girls } \\
\hline 1 & 4.35 & 28.3 & 1197 & 286 & 746 & 178 & 1942 & 464 & 447 & 107 \\
\hline 2 & 5.14 & 25.5 & 1490 & 356 & 672 & 161 & 2162 & 517 & 421 & 101 \\
\hline 3 & 5.82 & 21.2 & 1742 & 416 & 559 & 134 & 2301 & 550 & 395 & 94 \\
\hline 4 & 6.41 & 18.4 & 1960 & 469 & 285 & 68 & 2245 & 537 & 350 & 84 \\
\hline 5 & 6.92 & 15.5 & 2149 & 514 & 239 & 57 & 2389 & 571 & 345 & 83 \\
\hline 6 & 7.35 & 12.8 & 2309 & 552 & 199 & 47 & 2507 & 599 & 341 & 82 \\
\hline 7 & 7.71 & 11.0 & 2442 & 584 & 83 & 20 & 2525 & 604 & 328 & 78 \\
\hline 8 & 8.03 & 9.2 & 2561 & 612 & 69 & 17 & 2630 & 629 & 328 & 78 \\
\hline 9 & 8.31 & 8.4 & 2665 & 637 & 63 & 15 & 2728 & 652 & 328 & 78 \\
\hline 10 & 8.55 & 7.7 & 2754 & 658 & 74 & 18 & 2828 & 676 & 331 & 79 \\
\hline 11 & 8.78 & 6.6 & 2839 & 679 & 63 & 15 & 2902 & 694 & 331 & 79 \\
\hline 12 & 9 & 6.3 & 2920 & 698 & 60 & 14 & 2981 & 712 & 331 & 79 \\
\hline
\end{tabular}

${ }^{a} 50$ th percentile weight-for-age of the WHO pooled breast-fed data $\operatorname{set}^{36}$.

${ }^{b} 50$ th percentile weight increment of the WHO pooled breast-fed data set ${ }^{36}$. 
Table 7 Energy requirements for breast-fed infants $0-12$ months of age

\begin{tabular}{|c|c|c|c|c|c|c|c|c|c|c|}
\hline $\begin{array}{l}\text { Age } \\
\text { (months) }\end{array}$ & $\begin{array}{l}\text { Weight } \\
(\mathrm{kg})^{\mathrm{a}}\end{array}$ & $\begin{array}{l}\text { Weight } \\
\text { velocity } \\
\left(\text { g day }^{-1}\right)^{\mathrm{b}}\end{array}$ & $\begin{array}{l}\text { Total energy } \\
\text { expenditure } \\
\left(\mathrm{kJ}_{\text {day }}{ }^{-1}\right)\end{array}$ & $\begin{array}{l}\text { Total energy } \\
\text { expenditure } \\
\left.\text { (kcal day }^{-1}\right)\end{array}$ & $\begin{array}{l}\text { Energy } \\
\text { deposition } \\
\left(\text { kJ day }^{-1}\right)\end{array}$ & $\begin{array}{l}\text { Energy } \\
\text { deposition } \\
\left(\text { kcal day }^{-1}\right)\end{array}$ & $\begin{array}{l}\text { Energy } \\
\text { requirement } \\
\left(\mathrm{KJ} \mathrm{day}^{-1}\right)\end{array}$ & $\begin{array}{l}\text { Energy } \\
\text { t requirement } \\
\left(\mathrm{kcal}_{\text {day }}{ }^{-1}\right)\end{array}$ & $\begin{array}{c}\text { Energy } \\
\text { requirement } \\
\left(\mathrm{kJ} \mathrm{kg}^{-1} \text { per day }\right)\end{array}$ & $\begin{array}{c}\text { Energy } \\
\text { requirement } \\
\left(\mathrm{kcal} \mathrm{kg}^{-1} \text { per day }\right)\end{array}$ \\
\hline \multicolumn{11}{|l|}{ Boys } \\
\hline 1 & 4.58 & 35.2 & 1144 & 273 & 884 & 211 & 2027 & 485 & 443 & 106 \\
\hline 2 & 5.5 & 30.4 & 1501 & 359 & 764 & 183 & 2265 & 541 & 412 & 98 \\
\hline 3 & 6.28 & 23.2 & 1804 & 431 & 582 & 139 & 2386 & 570 & 380 & 91 \\
\hline 4 & 6.94 & 19.1 & 2060 & 492 & 224 & 53 & 2283 & 546 & 329 & 79 \\
\hline 5 & 7.48 & 16.1 & 2270 & 542 & 189 & 45 & 2458 & 588 & 329 & 79 \\
\hline 6 & 7.93 & 12.8 & 2444 & 584 & 150 & 36 & 2595 & 620 & 327 & 78 \\
\hline 7 & 8.3 & 11.0 & 2588 & 619 & 69 & 17 & 2657 & 635 & 320 & 77 \\
\hline 8 & 8.62 & 10.4 & 2712 & 648 & 65 & 16 & 2777 & 664 & 322 & 77 \\
\hline 9 & 8.89 & 9.0 & 2817 & 673 & 57 & 14 & 2874 & 687 & 323 & 77 \\
\hline 10 & 9.13 & 7.9 & 2910 & 696 & 89 & 21 & 2999 & 717 & 329 & 79 \\
\hline 11 & 9.37 & 7.7 & 3003 & 718 & 87 & 21 & 3091 & 739 & 330 & 79 \\
\hline $\begin{array}{l}12 \\
\text { Girls }\end{array}$ & 9.62 & 8.2 & 3100 & 741 & 93 & 22 & 3193 & 763 & 332 & 79 \\
\hline 1 & 4.35 & 28.3 & 1054 & 252 & 746 & 178 & 1800 & 430 & 414 & 99 \\
\hline 2 & 5.14 & 25.5 & 1361 & 325 & 672 & 161 & 2033 & 486 & 396 & 95 \\
\hline 3 & 5.82 & 21.2 & 1625 & 388 & 559 & 134 & 2184 & 522 & 375 & 90 \\
\hline 4 & 6.41 & 18.4 & 1854 & 443 & 285 & 68 & 2139 & 511 & 334 & 80 \\
\hline 5 & 6.92 & 15.5 & 2052 & 490 & 239 & 57 & 2291 & 548 & 331 & 79 \\
\hline 6 & 7.35 & 12.8 & 2219 & 530 & 199 & 47 & 2418 & 578 & 329 & 79 \\
\hline 7 & 7.71 & 11.0 & 2359 & 564 & 83 & 20 & 2442 & 584 & 317 & 76 \\
\hline 8 & 8.03 & 9.2 & 2483 & 593 & 69 & 17 & 2553 & 610 & 318 & 76 \\
\hline 9 & 8.31 & 8.4 & 2592 & 619 & 63 & 15 & 2655 & 635 & 319 & 76 \\
\hline 10 & 8.55 & 7.7 & 2685 & 642 & 74 & 18 & 2759 & 660 & 323 & 77 \\
\hline 11 & 8.78 & 6.6 & 2774 & 663 & 63 & 15 & 2838 & 678 & 323 & 77 \\
\hline 12 & 9 & 6.3 & 2860 & 684 & 60 & 14 & 2920 & 698 & 324 & 78 \\
\hline
\end{tabular}

${ }^{a} 50$ th percentile weight for age of the $\mathrm{WHO}$ pooled breast-fed data $\operatorname{set}^{36}$.

both percentile weight increment of the WHO pooled breast-fed data set ${ }^{36}$.

Table 8 Energy requirements for formula-fed infants 0-12 months of age

\begin{tabular}{|c|c|c|c|c|c|c|c|c|c|c|}
\hline $\begin{array}{l}\text { Age } \\
\text { (months) }\end{array}$ & $\begin{array}{l}\text { Weight } \\
(\mathrm{kg})^{\mathrm{a}}\end{array}$ & $\begin{array}{l}\text { Weight } \\
\text { velocity } \\
\left(\mathrm{g}_{\text {day }}{ }^{-1}\right)^{\mathrm{b}}\end{array}$ & $\begin{array}{l}\text { Total energy } \\
\text { expenditure } \\
\left(\mathrm{KJ} \mathrm{day}^{-1}\right)\end{array}$ & $\begin{array}{l}\text { Total energy } \\
\text { expenditure } \\
\left.\text { (kcal day }^{-1}\right)\end{array}$ & $\begin{array}{l}\text { Energy } \\
\text { deposition } \\
\left(\mathrm{kJ}^{\text {day }}{ }^{-1}\right)\end{array}$ & $\begin{array}{c}\text { Energy } \\
\text { deposition } \\
\left(\mathrm{kcal} \mathrm{day}^{-1}\right)\end{array}$ & $\begin{array}{l}\text { Energy } \\
\text { requirement } \\
\left(\mathrm{kJ} \mathrm{day}^{-1}\right)\end{array}$ & $\begin{array}{l}\text { Energy } \\
\text { requirement } \\
\left(\text { kcal day }^{-1}\right)\end{array}$ & $\begin{array}{c}\text { Energy } \\
\text { requirement } \\
\left(\mathrm{kJ} \mathrm{kg}^{-1} \text { per day }\right)\end{array}$ & $\begin{array}{c}\text { Energy } \\
\text { requirement } \\
\left(\mathrm{kcal} \mathrm{kg}^{-1} \text { per day }\right)\end{array}$ \\
\hline \multicolumn{11}{|l|}{ Boys } \\
\hline 1 & 4.58 & 35.2 & 1462 & 349 & 884 & 211 & 2345 & 560 & 512 & 122 \\
\hline 2 & 5.5 & 30.4 & 1779 & 425 & 764 & 183 & 2543 & 608 & 462 & 111 \\
\hline 3 & 6.28 & 23.2 & 2049 & 490 & 582 & 139 & 2631 & 629 & 419 & 100 \\
\hline 4 & 6.94 & 19.1 & 2277 & 544 & 224 & 53 & 2501 & 598 & 360 & 86 \\
\hline 5 & 7.48 & 16.1 & 2464 & 589 & 189 & 45 & 2653 & 634 & 355 & 85 \\
\hline 6 & 7.93 & 12.8 & 2619 & 626 & 150 & 36 & 2770 & 662 & 349 & 83 \\
\hline 7 & 8.3 & 11.0 & 2747 & 657 & 69 & 17 & 2816 & 673 & 339 & 81 \\
\hline 8 & 8.62 & 10.4 & 2858 & 683 & 65 & 16 & 2923 & 699 & 339 & 81 \\
\hline 9 & 8.89 & 9.0 & 2951 & 705 & 57 & 14 & 3008 & 719 & 338 & 81 \\
\hline 10 & 9.13 & 7.9 & 3034 & 725 & 89 & 21 & 3123 & 746 & 342 & 82 \\
\hline 11 & 9.37 & 7.7 & 3117 & 745 & 87 & 21 & 3204 & 766 & 342 & 82 \\
\hline 12 & 9.62 & 8.2 & 3203 & 766 & 93 & 22 & 3296 & 788 & 343 & 82 \\
\hline \multicolumn{11}{|l|}{ Girls } \\
\hline 1 & 4.35 & 28.3 & 1382 & 330 & 746 & 178 & 2128 & 509 & 489 & 117 \\
\hline 2 & 5.14 & 25.5 & 1655 & 396 & 672 & 161 & 2327 & 556 & 453 & 108 \\
\hline 3 & 5.82 & 21.2 & 1890 & 452 & 559 & 134 & 2449 & 585 & 421 & 101 \\
\hline 4 & 6.41 & 18.4 & 2094 & 500 & 285 & 68 & 2379 & 569 & 371 & 89 \\
\hline 5 & 6.92 & 15.5 & 2270 & 543 & 239 & 57 & 2510 & 600 & 363 & 87 \\
\hline 6 & 7.35 & 12.8 & 2419 & 578 & 199 & 47 & 2617 & 626 & 356 & 85 \\
\hline 7 & 7.71 & 11.0 & 2543 & 608 & 83 & 20 & 2626 & 628 & 341 & 81 \\
\hline 8 & 8.03 & 9.2 & 2654 & 634 & 69 & 17 & 2723 & 651 & 339 & 81 \\
\hline 9 & 8.31 & 8.4 & 2751 & 657 & 63 & 15 & 2814 & 673 & 339 & 81 \\
\hline 10 & 8.55 & 7.7 & 2834 & 677 & 74 & 18 & 2908 & 695 & 340 & 81 \\
\hline 11 & 8.78 & 6.6 & 2913 & 696 & 63 & 15 & 2976 & 711 & 339 & 81 \\
\hline 12 & 9 & 6.3 & 2989 & 714 & 60 & 14 & 3049 & 729 & 339 & 81 \\
\hline
\end{tabular}

${ }^{\text {a } 50 t h ~ p e r c e n t i l e ~ w e i g h t ~ f o r ~ a g e ~ o f ~ t h e ~ W H O ~ p o o l e d ~ b r e a s t-f e d ~ d a t a ~ s e t ~}{ }^{36}$.

${ }^{b} 50$ th percentile weight increment of the WHO pooled breast-fed data set ${ }^{36}$. 


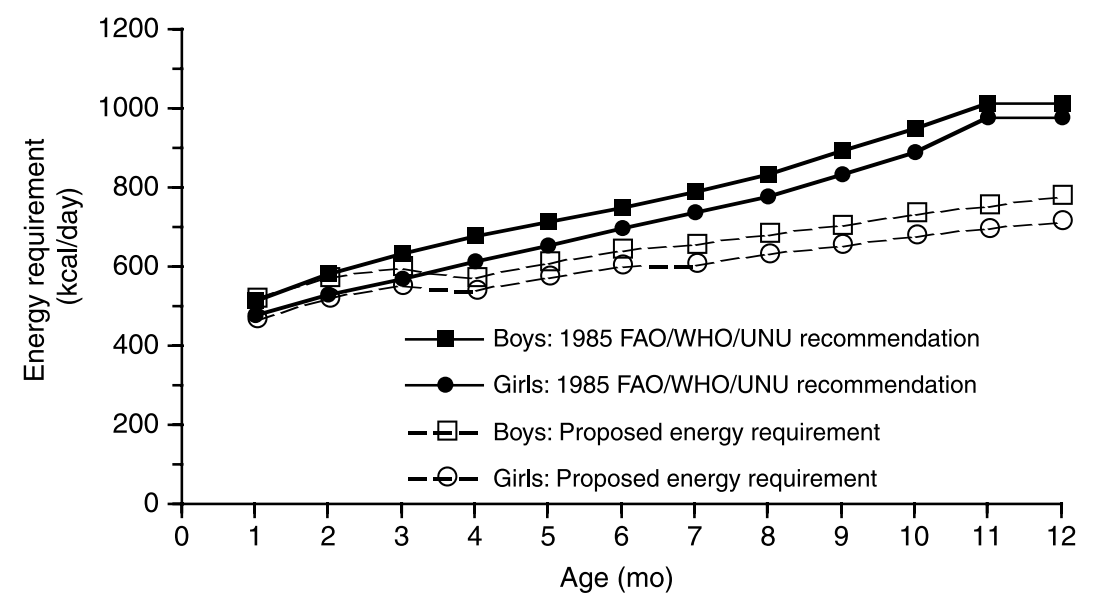

Fig. 3 The 1985 FAO/WHO/UNU recommendations ${ }^{1}$ for energy intake of infants (kcal day ${ }^{-1}$ ) vs. the proposed energy requirements for boys and girls

the average requirements of individual infants and should be determined from estimates of energy expenditure. The database of TEE determined by DLW is now sufficiently large to estimate average TEE during infancy. Body composition measurements are available to estimate energy deposition. Therefore, recommendations for energy intake of infants should be based upon measurements of TEE and energy deposition. The 1985 FAO/WHO/UNU recommendations are $10-32 \%$ higher than the total energy requirements estimated here within and should be revised.

\section{Areas for further research}

1. The number of available DLW studies on infants from developing countries is limited and should be expanded in normal-weight and IUGR infants. Further studies are needed to confirm whether the increased TEE observed in some settings is due solely to differences in size and body composition or other mitigating factors.
2. The DLW method provides a means of determining the amount of energy expended in physical activity. Physical activity levels consistent with normal health and development of infants should be described qualitatively and ethnographically across cultures.

3. Physiological adjustments in physical activity and growth in response to undernutrition should be investigated with more recent technologies.

4. The effect of the quality of dietary protein, carbohydrate and fat upon rates of weight gain, particularly during recovery from malnutrition, should be explored.

5. Nutrient needs for rehabilitation of stunted children are poorly understood. Special nutrient requirements for catch-up linear growth require further research.

6. The number of studies on the effect of infection on energy requirements of infants is limited, and should be expanded to cover a broad range of infectious agents of varying severity and duration.

7. Factors affecting the dietary intake that is necessary to satisfy energy requirements should be explored,

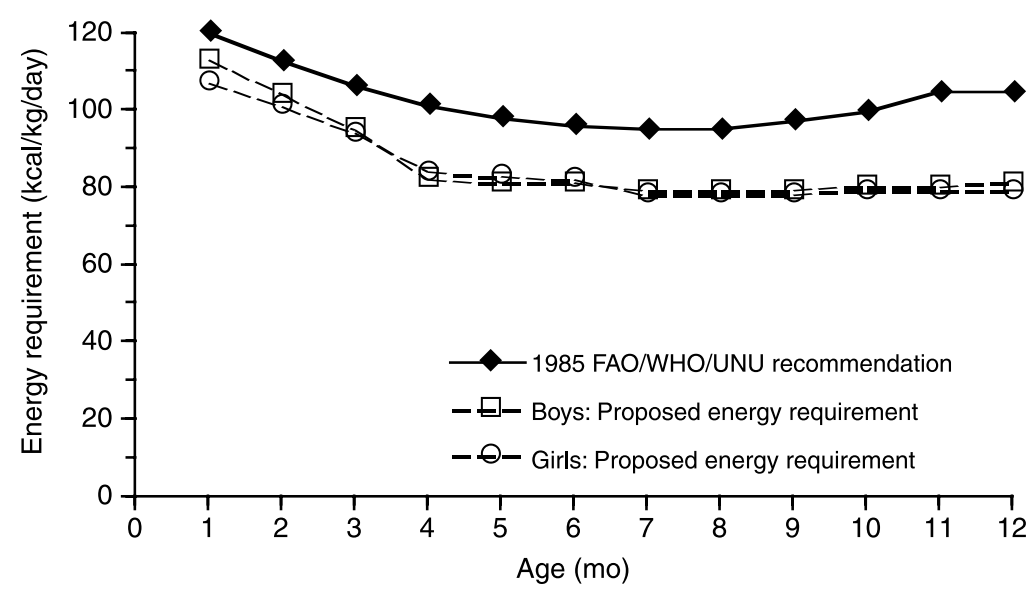

Fig. 4 The $1985 \mathrm{FAO} / \mathrm{WHO} / \mathrm{UNU}$ recommendations ${ }^{1}$ for energy intake of infants ( $\mathrm{kcal} \mathrm{kg}^{-1}$ per day) vs. the proposed energy requirements for boys and girls 
including diet digestibility, viscosity, and energy and nutrient density.

\section{Acknowledgements}

This work is a publication of the US Department of Agriculture (USDA)/Agricultural Research Service (ARS) Children's Nutrition Research Center, Department of Pediatrics, Baylor College of Medicine and Texas Children's Hospital, Houston, Texas. This project was funded in part with federal funds from the USDA/ARS under Cooperative Agreement 58-6250-6001. The contents of this publication do not necessarily reflect the views or policies of the USDA, nor does mention of trade names, commercial products, or organisations imply endorsement by the US Government.

\section{References}

$1 \mathrm{FAO} / \mathrm{WHO} / \mathrm{UNU}$ Expert Consultation. Energy and Protein Requirements. Geneva: WHO, 1985.

2 Fomon SJ. Infant Nutrition. Philadelphia: W.B. Saunders, 1974.

3 Dewey KG, Lönnerdal B. Infant self-regulation of breast milk intake. Acta Paediatrica Scandinavica 1986; 75: 893-8.

4 Butte NF. Energy Requirements of Infants. European Journal of Clinical Nutrition 1996; 50: S24-S36.

5 Whitehead RG, Paul AA, Cole TJ. A critical analysis of measured food energy intakes during infancy and early childhood in comparison with current international recommendations. Journal of Human Nutrition 1981; 35 $339-48$.

6 Fomon SJ, Haschke F, Ziegler EE, Nelson SE. Body composition of reference children from birth to age 10 years. American Journal of Clinical Nutrition 1982; 35: 1169-75.

7 Fomon SJ. Nutrition of Normal Infants. St. Louis: MosbyYear Book, Inc., 1993.

8 Watt BK, Merrill AL. Composition of Foods. Washington, DC: US Government Printing Office, 1963.

9 Southgate DAT, Barrett IM. The intake and excretion of calorific constituents of milk by babies. British Journal of Nutrition 1966; 20: 363-72.

10 Holliday MA. Metabolic rate and organ size during growth from infancy to maturity and during late gestation and early infancy. Pediatrics 1971; 47: 169-79.

11 Butte NF. Basal metabolism of infants. In: Schürch B, Scrimshaw NS, eds. Activity, Energy Expenditure and Energy Requirements of Infants and Children. Switzerland: Nestlé Foundation, 1989, 117-37.

12 Karlberg P. Determinations of standard energy metabolism (Basal Metabolism) in normal infants. Acta Paediatrica Scandinavica 1952; 41: 13-151.

13 Benedict FG, Talbot FB. Metabolism of Growth from Birth to Puberty. Washington, DC: Carnegie Institute, 1921.

14 Schofield WN, Schofield C, James WPT. Basal metabolic rate - review and prediction, together with an annotated bibliography of source material. Human Nutrition: Clinical Nutrition 1985; 39C: 1-96.

15 Wells JCK, Davies PSW. Energy cost of physical activity in twelve week old infants. American Journal of Human Biology 1995; 7: 85-92.

16 Butte NF, Wong WW, Hopkinson JM, Heinz CJ, Mehta NR, Smith EO. Energy requirements derived from total energy expenditure and energy deposition during the first 2 years of life. American Journal of Clinical Nutrition 2000; $\mathbf{7 2}$ 1558-69.

17 Wells JCK, Joughin C, Crisp JA, Cole TJ, Davies PSW Comparison of measured sleeping metabolic rate and predicted basal metabolic rate in the first year of life. Acta Paediatrica Scandinavica 1996; 85: 1013-18.

18 Danforth E. Diet and obesity. American Journal of Clinical Nutrition 1985; 41: 1132-45.

19 Reichman BL, Chessex P, Putet G. Partition of energy metabolism and energy cost of growth in the very low birth weight infant. Pediatrics 1982; 69: 446-51.

20 Ashworth A. Metabolic rates during recovery from proteincalorie malnutrition: the need for a new concept of specific dynamic action. Nature 1969; 223: 407-9.

21 Hill JR. The development of thermal stability in the newborn baby. In: Jonxis JHP, Visses HKA, Troelstra JA, eds. The Adaptation of the Newborn to Extrauterine Life. Leiden: H.E. Stenfert Kroese, 1964, 223-8.

22 Penn D, Schmidt-Sommerfeld E. Lipids as an energy source for the fetus and newborn infant. In: Lebenthal E, ed. Textbook of Gastroenterology and Nutrition in Infancy. New York: Raven Press, 1989, 293-310.

23 Talbot FB. Twenty-four hour metabolism of two normal infants with special references to the total energy requirements of infants. American Journal of Diseases of Children 1917; 14: 25.

24 Lawrence M, Lawrence F, Durnin JV, Whitehead RG. A comparison of physical activity in Gambian and UK children aged 6-18 months. European Journal of Clinical Nutrition 1991; 45: 243-52

25 Roberts SB, Coward WA, Schlingenseipen K-H, Nohria V, Lucas A. Comparison of the doubly labelled water $\left({ }^{2} \mathrm{H}_{2}^{18} \mathrm{O}\right)$ method with indirect calorimetry and a nutrient-balance study for simultaneous determination of energy expenditure, water intake, and metabolizable energy intake in preterm infants. American Journal of Clinical Nutrition 1986; 44: 315-22.

26 Jones PJH, Winthrop AL, Schoeller DA, Swyer PR, Smith J, Filler RM, Heim T. Validation of doubly labelled water for assessing energy expenditure in infants. Pediatric Research 1987; 21: 242-6.

27 Westerterp KR, Lafeber HN, Sulkers EJ, Sauer PJJ. Comparison of short term indirect calorimetry and doubly labelled water method for the assessment of energy expenditure in preterm infants. Biology of the Neonate Bio 1991; 60: 75-82.

28 Jensen CL, Butte NF, Wong WW, Moon JK. Determining energy expenditure in preterm infants: comparison of ${ }^{2} \mathrm{H}_{2}^{18} \mathrm{O}$ method and indirect calorimetry. American Journal of Physiology 1992; 32: R685-92.

29 Butte NF, Wong WW, Ferlic L, Smith EO. Energy expenditure and deposition of breast-fed and formulafed infants during early infancy. Pediatric Research 1990; 28: $631-40$.

30 Jiang Z, Yan Q, Su Y, Heson KJ, Thélin A, Piguet-Welsch C, Ritz P, Ho Z. Energy expenditure of Chinese infants in Guangdong Province, South China, determined with use of the doubly labelled water method. American Journal of Clinical Nutrition 1998; 67: 1256-64.

31 Davies PSW, Ewing G, Coward WA, Lucas A. Energy metabolism in breast-fed and formula-fed infants. In: Atkinson SA, Hanson LÅ, Chandra RK, eds. Breast-feeding, Nutrition, Infection and Infant Growth in Developed and Emerging Countries. St. John's Newfoundland: Arts Biomedical, 1990, 521.

32 Butte NF, Villalpando S, Wong WW, Flores-Huerta S, Hernandez-Beltran M, Smith EO. Higher total energy expenditure contributes to growth faltering in breast-fed infants living in rural Mexico. Journal of Nutrition 1993; 123 $1028-35$. 
33 Fjeld CR, Schoeller DA. Energy expenditure of malnourished children during catch-up growth. Proceedings of the Nutrition Society 1988; 47: 227-31.

34 Butte NF, Wong WW, Garza C. Energy cost of growth during infancy. Proceedings of the Nutrition Society 1989; 48: 303-12.

35 de Bruin NC, Degenhart HJ, Gàl S, Westerterp KR, Stijnen T, Visser HKA. Energy utilization and growth in breast-fed and formula-fed infants measured prospectively during the first year of life. American Journal of Clinical Nutrition 1998; 67 : 885-96.

36 World Health Organization. WHO Working Group on Infant Growth. An Evaluation of Infant Growth. Geneva: Nutrition Unit, WHO, 1994.

37 Waterlow JC. Energy and protein requirements of infants and young children. Protein-energy Malnutrition. London: Edward Arnold, 1992, 222-59.

38 Ashworth A, Millward DJ. Catch-up growth in children. Nutrition Review 1986; 44: 157-63.

39 Parra A, Garza C, Garza Y, Saravia JL, Hazlewood CF, Nichols BL. Changes in growth hormone, insulin, and thyroxine values, and in energy metabolism of marasmic infants. Journal of Pediatrics 1973; 82: 133-42.

40 Montgomery RD. Changes in the basal metabolic rate of the malnourished infant and their relation to body composition. Journal of Clinical Investigation 1962; 41: 1653-63.

41 Young VR. Protein-energy interrelationships in the newborn: a brief consideration of some basic aspects. In: Lebenthal E, ed. Textbook of Gastroenterology and Nutrition in Infancy. New York: Raven Press, 1981, 257-63.

42 Fjeld CR, Schoeller DA, Brown KH. Body composition of children recovering from severe protein-energy malnutrition at two rates of catch-up growth. American Journal of Clinical Nutrition 1989; 50: 1266-75.

43 MacLean WC Jr., Graham GG. The effect of energy intake on nitrogen content of weight gained by recovering malnourished infants. American Journal of Clinical Nutrition 1980; 33: 903-9.

44 Graham GG, Cordano A, Blizzard RM, Cheek DB. Infantile malnutrition. Changes in body composition during rehabilitation. Pediatric Research 1969; 3: 579-89.

45 Fjeld CR, Schoeller DA, Brown KH. A new model for predicting energy requirements of children during catch-up growth developed using doubly labelled water. Pediatric Research 1989; 25: 503-8.

46 World Health Organization. Malnutrition in adolescents and adults. Management of Severe Malnutrition: a Manual for Physicians and Other Senior Health Workers. Geneva: WHO, 1999, 37-40.

47 Waterlow JC, Tomkins AM. Nutrition and infection. Protein Energy Malnutrition. London: Edward Arnold, 1992, 290-324.

48 Duggan MB, Milner RDG. Energy cost of measles infection. Archives of Disease in Childhood 1986; 61: 436-9.

49 Eccles MP, Cole TJ, Whitehead RG. Factors influencing sleeping metabolic rate in infants. European Journal of Clinical Nutrition 1989; 43: 485-92.

50 Prentice AM, Paul AA. Fat and energy needs of children in developing countries. American Journal of Clinical Nutrition 2000; 72: S1253-S65.

51 Lucas A, Ewing G, Roberts SB, Coward WA. How much energy does the breast-fed infant consume and expend? British Medical Journal 1987; 295: 75-7.

52 Vasquez-Velasquez L. Energy expenditure and physical activity of malnourished Gambian infants. Proceedings of the Nutrition Society 1988; 47: 233-9.

53 Roberts SB, Savage J, Coward WA, Chew B, Lucas A. Energy expenditure and intake in infants born to lean and overweight mothers. New England Journal of Medicine 1988; 318: 461-6.

54 Davies PSW, Ewing G, Lucas A. Energy expenditure in early infancy. British Journal of Nutrition 1989; 62: 621-9.

55 Davies PSW, Day JME, Lucas A. Energy expenditure in early infancy and later body fatness. International Journal of Obesity 1991; 15: 727-31.

56 Wells JCK, Cole TJ, Davies PSW. Total energy expenditure and body composition in early infancy. Archives of Disease in Childhood 1996; 75: 423-6.

57 Davies PSW, Wells JCK, Hinds A, Day JME, Laidlaw A. Total energy expenditure in 9 month and 12 month infants. European Journal of Clinical Nutrition 1997; 51: 249-52.

58 Stunkard AJ, Berkowitz RI, Stallings VA, Schoeller DA. Energy intake, not energy output, is a determinant of body size in infants. American Journal of Clinical Nutrition 1999; 69: $524-30$

59 Salazar G, Vio F, Garcia C, Aguirre E, Coward WA. Energy requirements in Chilean infants. Archives of Disease in Childhood: Fetal and Neonatal Edition 2000; 83: F120-3.

60 Davies PSW, Coward WA, Gregory J, White A, Mills A. Total energy expenditure and energy intake in the pre-school child: a comparison. British Journal of Nutrition 1994; 72 : 13-20.

61 Prentice AM, Lucas A, Vasquez-Velasquez L, Davies PSW, Whitehead RG. Are current dietary guidelines for young children a prescription for overfeeding? Lancet 1988; 2: 1066-9.

62 Kerr D. Accelerated recovery from infant malnutrition with high calorie feeding. In: Gardner L, Amacher L, eds. Endocrine Aspects of Malnutrition. Santa Ynez: Kroc Foundation, 1973, 467-79.

63 Spady DW, Payne PR, Picou D, Waterlow JC. Energy balance during recovery from malnutrition. American Journal of Clinical Nutrition 1976; 29: 1073-8.

64 Jackson AA, Picou D, Reeds PJ. The energy cost of repleting tissue deficits during recovery from protein-energy malnutrition. American Journal of Clinical Nutrition 1977; 30: $1514-7$.

65 Graham GG, MacLean WC Jr, Brown KH, Morales E, Lembcke J, Gastañaduy A. Protein requirements of infants and children: growth during recovery from malnutrition. Pediatrics 1996; 97: 499-505.

66 Brooke OG, Alvear J, Arnold M. Energy retention, energy expenditure, and growth in healthy immature infants. Pediatric Research 1979; 13: 215-20.

67 Chessex P, Reichman BL, Verellen GJE, Putet G, Smith JM, Heim T, Swyer PR. Fetal and neonatal medicine. Journal of Pediatrics 1981; 99: 761-6.

68 Gudinchet F, Schutz Y, Micheli J-L, Stettler E, Jequier E. Metabolic cost of growth in the very low-birth weight infants. Pediatric Research 1982; 16: 1025-30.

69 Whyte RK. Energy cost of growth of premature infants. Acta Paediatrica Academica Scientarium Hungarica 1982; 23: 85-98.

70 Food and Nutrition Board. Recommended Dietary Allowances. Washington, DC: National Academy Press, 1989.

71 Freymond D, Schutz Y, Decombaz J, Micheli JL, Jequier E. Energy balance, physical activity and thermogenic effect of feeding in premature infants. Pediatric Research 1986; 20: 638-45.

72 Roberts SB, Young VR. Energy costs of fat and protein deposition in the human infant. American Journal of Clinical Nutrition 1988; 48: 951-5.

73 Butte NF, Hopkinson JM, Wong WW, Smith EO, Ellis KJ. Body composition during the first two years of life: an updated reference. Pediatric Research 2000; 47: 578-85. 